\title{
Managing Heutagogy as Innovation Strategy for Productivity Improvement among Medical Representatives in Remote Areas During Covid-19
}

\author{
Daniel Kisahwan ${ }^{1}$, Justine Tanuwijaya ${ }^{2}$, Deni Hermana ${ }^{3}$ \\ \{kisahwand@gmail.com ${ }^{1}$, justine@trisakti.ac.id ${ }^{2}$, hermana.deni@yahoo.com ${ }^{3}$ \} \\ University of Trisakti, Economy and Business Faculty ${ }^{1,2}$, University of Pakuan ${ }^{3}$
}

\begin{abstract}
Humanitarian disaster has prohibited employee productivity. On the other hand, Covid-19 pandemic has promoted faster digitalization process for employees in remote areas, including Medical Representatives in pharmaceutical companies. Even though there are some limitations in terms of infrastructures as well as technological operation ability among medical representatives. They are still making efforts to implement information technology in remote areas as a challenge for digitalization to maintain and increase their productivity. The research goal is to analyze heutagogy management as innovation strategy to encourage improvement in Medical Representative productivity. The research method is using causal method with 87 samples of medical representatives from Japanese company that were chosen randomly whom work in remote areas such as Jayapura, Tarakan, Ketapang, Palopo, Palu, and Ternate. Data analysis using SEM PLS with online questionnaires. Competencies, skills, and confidence in using technology both for Medical Representatives and doctors/health workers will boost success in productivity increase from Medical Representatives. Practical implication is the increase management of heutagogy of Medical Representatives for remote areas. Value contribution is the strategic development in heutagogy management for both Medical Representatives and doctors/health workers in remote areas.
\end{abstract}

Keywords: Managing heutagogy; medical representative; remote area; innovation strategy; productivity; doctor/health worker.

\section{Introduction}

Humanity disaster has encouraged a change in the interaction between individuals at work. The COVID-19 pandemic has affected various sectors; primary, secondary, and tertiary. The use of information technology to help the social interaction process has increased [1], [2]. The COVID-19 pandemic has driven digitalization process to come faster. Digitalization and the change in the interaction pattern at work have motivated companies to develop strategies to help organizations maintaining their productivity, and even more increasing their productivity, including pharmaceutical companies. However, various limitations on the use of information 
technology become obstacles for pharmaceutical company employees, such as medical representatives. They have not fully used the information technology to support their productivity, including doctors or health workers who work in remote areas. They are faced with various obstacles, such as infrastructures as well as readiness in using technology like in Kalimantan, Sulawesi and Papua. This condition is also experienced by Japanese PMA pharmaceuticals. Medical representatives are facing the following obstacles: 1) inadequate infrastructure especially the limited network and internet connection in remote areas, 2) ability of medical representatives to implement digitalization, 3) readiness of doctors/health workers to accept digitalization in their interaction with medical representatives. A lot of medical representatives experience obstacles in their marketing efforts, causing them to express burnouts and lower involvement level [3], [4].

The challenge that must be faced by medical representatives is to organize self-directed learning to integrate marketing activities with technology in order to interact with doctors/health workers in remote areas to stay productive. Even though heutagogy management in theory can direct learning process and become conceptual framework for managing digital learning, but the actual practice is very limited. Medical representatives are expected to be able to develop skills in organizing learning with self-directed learning concept as a prerequisite for digitalization integration to maintain and increase productivity at work.

Heutagogy is a term created by Stewart Hase from Southern Cross University and Chris Kenyon in Australia [5]. Heutagogy is referred to as self-directed learning. Heutagogy applies a holistic approach to develop students' ability to learn, with learning as both active and proactive process. In this approach students are the main agents for their own learning, which occurs as a result of personal experience, as a double cycle of learning and self reflection. Heutagogy integrates resources for learning sources, especially the development in information and technology.

This informal and/or non-formal learning environment can be inspiring, innovative, and interesting for students. Learning environment can help motivate students and is prospective to be used as learning sources.

Heutagogy has a self-directed learning (SDL) concept, in which learners who determine the direction (user directed), variation (variarty), analytical learning (learning analytic), motivation (motivation), and knowledge sharing (sharing) [6]. The focus is on managing learning changes so that students understand learning by integrating technology into learning. Karakas dan Manisaligil (2012) explains on virtual collaboration to expand knowledge access and innovation together [7]. Technological convergence makes it easier to increase learning activities with technology. With global connectivity, connecting to the internet can provide access to the world and meaningful online communities also engage in problem-oriented activities. Digital creativity builds ability and creative strength, and emphasizes participants' awareness of the meaning of learning methods. Learning context needs to be redesigned with the flexibility to meet individual needs, in which the learning format will integrate technology based on self-directed learning concept. Thus this can minimize obstacles in learning [8]. Learning process in heutagogy can be described as the following: 


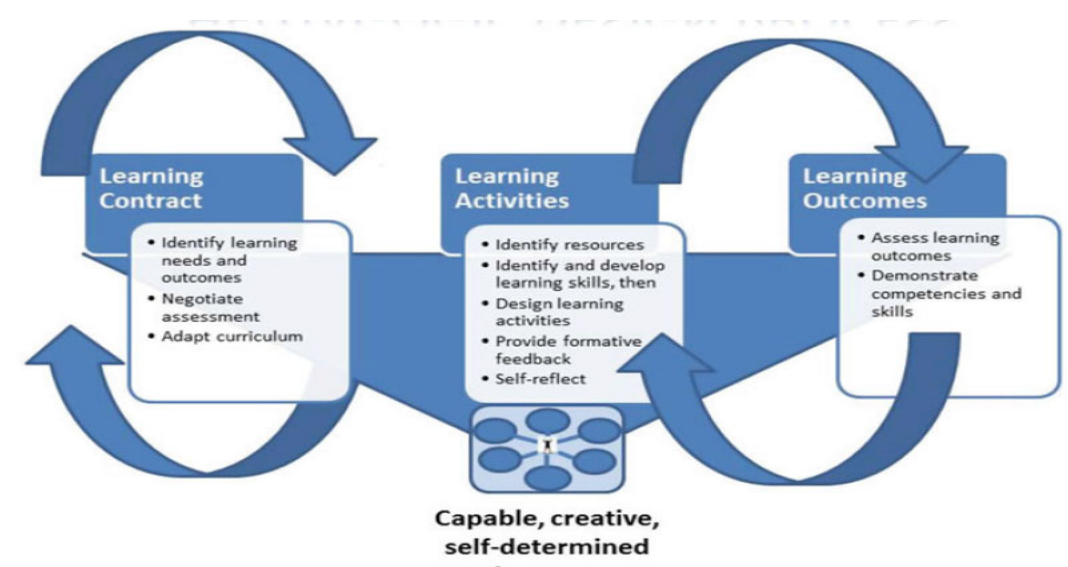

Fig. 1. Desain proses Heutagogy [9], [10]

Heutagogy integrates resources for learning source especially the development of technology and information. Therefore, governance is needed as an art and science. Heutagogy management is a process of planning, implementing, and evaluating of the learning process on how to learn based on the importance of independent learning [10]. Heutagogy management describes a change in learning architecture [11]. Learning architecture and learning design need to be improved according to their function and equipped with various new tools, strategies, and learning delivery platforms so that learning becomes interesting, even addictive for learners. Fundamental questions related with heutagogy is: What interests a person? How to expore it? What is the desirable learning process? These questions are based on critics towards learning process that ignores learning as learning subjects and not as a part of a mechanical production process [12]. Rooted learning habit and finding new learning approaches as learners by integrates technology into the characteristics of heutagogy. Heutagogy limitation means a teaching and learning approach that is facilitated by a mentor/teacher which determines independent learning [12].

Heutagogy practically helps company's education and training system to go smooth as a desired process. Company can boost productivity through the implementation of self learning model that integrates information technology and performance system. Heutagogy is a necessary skill in education at workplace [13]. Heutagogy is an approach in professional development in human resource governance [14]. The result of study by Hia shows that learning governance such as heutagogy encourages business activities in the retirement group [10]. The increased ability to generate value in the retirement group is based on understanding of learning methods that are continuously developed independently. Heutagogy approach can improve students' productive ability in batik [15]. Technology design that is matched with the needs will increase self-directed learning process. Heutagogy's position in enhancing individual ability is very important [16], [17]. Although there is a fact about heutagogy position, exploration into the process in the context of medical representative in remote areas has never been done. Even though medical representative profession is faced with various job demands that requires learning process to solve every problem while continuing to carry promotions and marketing. The success of medical representatives in relation to work productivity depends on the learning process experienced.

The productivity of medical representatives has become orientation of pharmaceutical companies, because they are the spearhead in promotion and marketing. Productivity can be 
produced through learning process that integrates technology and independent learning in an integrated design. Performance review of employees in a pharmaceutical companies is very important [18].

Therefore, the emphasis on the process becomes more important than the output in the form of sales. Medical representatives as company's representative for the expansion of medical knowledge in scientific community, and for improving the efficiency of diagnostic and treatment which improves the quality of health [19]. Medical representatives' duties are to implement pharmaceutical company framework that is based on respect for legal, ethical, and scientific principles, and to promote rational use of medicines to prevent unethical practices by acting as a reliable reference for marketing practices [20]. The statement confirms that medical representatives' duty is not only focused on sales but rather on delivering the correct use and the latest information about treatment management that is conveyed to health workers partners according to the relevant ethic code in order to encourage independent public health, including in remote areas.

Therefore an innovative approach is needed so that medical representatives can carry out their duties optimally. Managing heutagogy is an innovative step in the middle of COVID-19 pandemic humanitarian disaster and limited numbers of doctors/health workers in remote areas to use digital technology. However, the practice of heutagogy in remote areas is still unclear. Firstly, the results of the research are expected to encourage increased employees" productivity through self-directed learning process and to provide understanding in the importance of building learning collaboration in remote areas [21], [22]. Increased skills will reduce obstacles in using communication technology and utilize available information features for work purposes including work partners. This research is expected to give contribution towards innovation management study. Innovations in relation with company performance is extremely important [23]. Secondly, the results of this research can provide conceptual framework in relation with medical representatives " productivity during COVID-19 pandemic in an innovative way. Thirdly, the results of this research can be used as a basis in developing company's education and training system with heutagogy approach for employees in remote areas. The purpose of this research is to analyze heutagogy management implementation as an innovation strategy to increase medical representatives ' productivity.

\section{Research Methodology}

Data analysis used causality test procedure. Research population is 120 medical representatives whom work in the remote areas of Jayapura, Tarakan, Ketapang, Palopo, Palu, and Ternate. Samples were taken randomly for as many as 87 medical representatives. Heutagogy management measures were developed based on focus on the principles of developed heutagogy management, namely; a) designing learning acitivity which enocurage participation, personalization, and productivity; b) using open tools and platforms; c) combining authentic learning that support exploration and experimentation; d) using formative and ongoing assessment; and e) providing the necessary technical support to use media tools [24]. To ensure heutagogy learning process ran according to the objectives, heutagogy management process was developed in line with the concepts of heutagogy management for retirees [10]. Medical representatives ' productivity was developed based on the orientation of promotion of medicines through visits to doctors/health workers [19], [20]. In this research, productivity was measured based on process and interactions within medical representatives in remote areas to minimize communication barriers in expanding access to information for the 
purpose of promoting medicines through visits to doctors either directly or virtually. Statistical analysis procedure used SEM PLS analysis to identify the principles in heutagogy that encourage productivity.

\section{Results And Discussion}

Generally, the principles in heutagogy learning have been implemented but not yet optimal. The results show that the average ability to manage heutagogy learning among medical representatives are in the low category. Although it is recognized that the productivity of medical representatives is in the the sufficient category. The test results show heutagogy principles in explaning construction of the heutagogy management governance. These principles serve as the basis of heutagogy management implementation.

Heutagogy principle has become a foundation in heutagogy learning, heutagogy management cannot ignore the principles of: a) designing learning acitivity which enocurage participation, personalization, and productivity; b) using open tools and platforms; c) combining authentic learning that support exploration and experimentation; d) using formative and ongoing assessment; and e) providing the necessary technical support to use media tools [24]. The test results show that the value of the factors weight for each principle is acceptable. The average AVE value is in the high category, which is above 0.6. The test results with SEM PLS procedure are as follows:

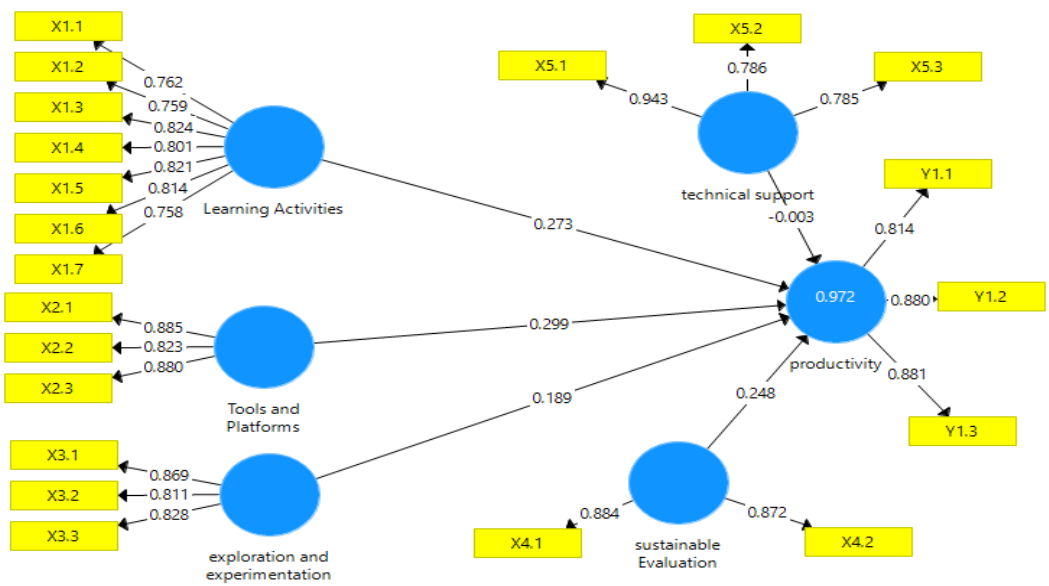

Fig. 2. Full Model

The test results show acceptable values of Convergent Validity, Discriminant Validity, and Composite Reliability. Each indicator can explain latent variable in an acceptable level. Loading factor value is $>0,6$ for number of samples 87. Average Variance Extracted (AVE) test results show that the average is able to explain latent variable at a fairly high value. Acceptable Composite Reliability $(>0,6)$ means that it has acceptable reliability contruct value. Overall, the test results of outer model can be seen as follows: 
Table 1. Construct Validity and Reliability

\begin{tabular}{lccc}
\hline & Cronbach 'Alpha & Composite reliability & Ave \\
\hline Learning activity & 0.901 & 0.922 & 0.627 \\
Tools and platform & 0.828 & 0.897 & 0.744 \\
Exploration and experiment & 0.784 & 0.874 & 0.699 \\
Sustainable evaluation & 0.703 & 0.871 & 0.771 \\
Technical support & 0.859 & 0.878 & 0.708 \\
Productivity & 0.822 & 0.894 & 0.738 \\
\hline
\end{tabular}

Source : The result from SEM PLS

The test results of discriminant validity can be known based on the cross loading values that show each indicator as observed variable that has high correlation level with latent variable, discriminant validity is considered good. The results of the evaluation on the structural model that represents correlation between the researches variables (inner model) based on the concepts constructed by the researchers are as follows:

Table 2. Direct effect from independent variables to dependent variable

\begin{tabular}{lcccc}
\hline Channel & Coefficient Regression (Standardized) & t-statistic & Result & R-square \\
\hline $\mathrm{X} 1 \rightarrow \mathrm{Y}$ & 0,273 & 2.636 & Significant & 0.972 \\
$\mathrm{X} 2 \rightarrow \mathrm{Y}$ & 0,299 & 2.604 & Significant & \\
$\mathrm{X} 3 \rightarrow \mathrm{Y}$ & 0,189 & 1.576 & Not Significant & \\
$\mathrm{X} 4 \rightarrow \mathrm{Y}$ & 0,248 & 2.385 & Significant & \\
$\mathrm{X} 5 \rightarrow \mathrm{Y}$ & -0.003 & 0.151 & Not Significant & \\
\hline
\end{tabular}

Source : The result from SEM PLS

Principles that are implemented in the self-directed learning process have significant effect on productivity statistically. The effect of X2, which is a tool and significant platform, towards productivity with statistic $t$ value of 2.604. Continuous evaluation has a significant effect on productivity. Evaluation is an ongoing assessment related with expectation and reality based on a number of achievement indicators. The better the evaluation, the higher the productivity as long as evaluation produces a critical reflection towards every medical representatives“ work activity. However, the effect on exploration and experiment (X3) and technical support that carried out by medical representatives with doctors is not significant. This is based on the weaknesses of exploration and experiment activity for the development of learning resources and discussion on the latest treatment management. Interaction between medical representatives and doctors as well as other medical representatives are limited. Negative effect is shown by sub variable (X5) on productivity. Providing the necessary support to use media tools for doctors/health workers actually hinders productivity. This shows the importance of assistance by experienced technicians who have high level ability to understand information technology to support learning process between doctors and medical representatives as well as other medical representatives. The involvement of medical representatives at work, such as assisting the installation of standard software/hardware such as input device, process device, output device, backing storage, periferal, hinders interaction between medical representatives and doctors/health workers. Interaction process in independent learning requires support from technicians who can provide suggestions to doctors and medical representatives to apply for server downtime assistance, server performance monitoring, feature troubleshooting, problematic panel, and organize remote hosting client for more in-depth handling.

Research results show that the application of heutagogy principles can promote increased productivity. Limitations in conducting exploration and experimentation related with 
information, approaches, new learning resources, and intensive intreaction with doctors/health workers and medical representatives are not possible. This causes the principles inapplicable and has no signifcant effect on productivity. The influence is in the less category. The same is true in applying technical support principle. Impossible conditions cause medical representatives unable to apply the principles.

In general, it can be stated that the research results are in line with the concept put forward by Chen et al., Ali et al., who explains various barriers in the implementation of information technology system in remote areas, especially in the infrastructures and technical support in applying information technology [3], [4]. That condition cause barriers in learning process and eventually reduce optimization of heutagogy function to increase productivity. In line with Hia; Karakas and Manisaligil who suggest that heutagogy as virtual collaboration to understand learning how to learn [7], [10].

The success of organizing heutagogy to improve productivity is based on the initiative of medical representatives to plan, implement, and evaluate self-directed learning experience, including in remote areas. This form of learning can take place both inside and outside the institutional-based learning program which is organized by companies or by the initiative of medical representatives. Self direction in learning is a natural part of medical representatives as adults. Heutagogy in the era of information technology acts as an interactive process between medical representatives with doctors and other medical representatives. The success of that learning is based on the implementation of heutagogy principles.

Principles implementation between medical representatives and doctors/health workers (including learning how to learn related with COVID-19 pandemic condition and learning technology) with learning contents, technology. The success of the learning process cannot ignore the position of collaboration among doctors and medical representatives. Both parties are learning subjects who interact and communicate to build a learning approach by integrating technology with self-directed learning. Medical representatives learn to adapt on various problems in remote areas, both related to technology application in productive learning as well as understand the limitations of doctors/health workers interacting with technology. Doctors/health workers learn to cope with digitalization in carrying out their duties. Collaboration allows the implementation of self-directed learning process, in line with Kamrozzaman et al., about the meaning of collaboration in learning process, as well as confirmed with Stenman dan Petterson [21], [22]. Both learning subjects share their knowledge as conceptualized by Firat et al., the process encourages self-directed learning ability [6]. Limited technical support causes the implementation of heutagogy as a process to increase productivity to be hindered. Virtual collaboration experiences obstacles to expand learning sources among medical representatives and doctors related to updated information on treatment management due to the lack of technical support. Stenman and Petterson; and Kamrozzaman et al., explain the importance of collaboration in learning, including in remote areas [21], [22].

Judging from learning process experience, medical representatives can improve their capability to solve problems and deal with challenges as explained by Darwish et al., about the condition of medical representatives in their work [25]. Self-directed learning process, which is implemented based on principles mentioned by Blaschke dan Marin; Firat et al., as a strategic innovation to improve the productivity of medical representatives in remote areas [6], [24]. The research results prove that heutagogy concept can be accepted as a strategic innovation to increase productivity. Heutagogy as a concept of self-directed learning that expands human agent role in learning process [9], [26], [27]. Heutagogy improves capabilities and encourages medical representatives to solve problems based on knowledge reflected 
through a self-directed learning process in remote areas. Heutagogy is an innovative process option to optimize productivity through a self-directed learning process on how to learn during COVID-19 pandemic. Independence in learning, learning methods, and learning principles implementation improve the productivity capability of medical representatives. Innovation in order to increase companies “ performance [23]. Pharmaceutical industries have evolved from year to year, marked by competitive markets [28]. Increased understanding on learning how to learn will encourage knowledge acquisition that will be used as tools to update information about treatment management for doctors and promotional actions for medical representatives.

Interaction among learning participants as a representation of awareness on learning method means. Full participation and freedom in dialogues expand understanding of critical self-directed methods for the ongoing needs of the learning process. Full participation as a resource to develop autonomy in self-directed learning. Self-directed learning in heutagogy directs students' abilities in directing themselves to their study, encourages transformational learning by integrating the availability of technology and information with principles and productive orientation, and promoting emancipatory action in learning and social actions as an integral part of self-directed learning. In line with Bailey who explains on heutagogy as a learning concept model to encourage and support professionals and the development of human resource practitioners [14]. The heutagogy designed is the experience of medical representatives that reflects various forms of non-formal learning, such as through visits, mentoring, meeting with colleagues and talking with doctors, providing information, discussion, and even enquiry for help to expand networks by listening to doctors' opinions, reflection and find out how to learn with the support of information technology. Various selfdirected learning activities are structurally encouraged as a part of education and training for medical representatives to improve productivity.

\section{Conclusion}

Heutagogy is an innovation in an effort to increase the productivity of medical representatives. The success in applying the principles in the heutagogy learning process can improve the productivity of medical representatives. Heutagogy helps the company's education and training system to improve the ability of medical representatives on selfdirected learning methods which in the end encourages productivity. The theoretical implication is the need to develop heutagogy with the concept of integrated information management. Practical implication is to develop learning culture within the company to encourage self-directed learning as the competitive value from the company. Further research on the development of heutagogy learning models according to the orientation and structure of Human Resource governance.

\section{References}

[1] A. Somov, "Wildfire safety with wireless sensor networks," EAI Endorsed Trans. Ambient Syst., vol. 1, no. 1, 2011, doi: 10.4108/trans.amsys.2011.e4.

[2] M. A. Azeem, "Start programming using Object Pascal," Leg. Free Comput. Books, vol. 2, hlm. 10-11, 2013.

[3] S. C.-I. Chen dan C. Liu, "Factors Influencing the Application of Connected Health in Remote Areas, Taiwan: A Qualitative Pilot Study," Int. J. Environ. Res. Public Health, 
vol. 17 , no. 4, hlm. 1282, 2020.

[4] M. A. Ali, K. Alam, dan B. Taylor, "Measuring the concentration of information and communication technology infrastructure in Australia: Do affordability and remoteness matter?," Socioecon. Plann. Sci., vol. 70, no. C, 2020, doi: 10.1016/j.seps.2019.10073.

[5] L. Blaschke dan C. Kenyon, Experiences in Self-Determinded Learning. Scotts Valley: CreateSpace Independent Publishing Platform, 2014.

[6] M. Firat, N. Sakar, dan I. K. Turdakul, "Web Interface Design Principles For Adults, Self-directed Learning Self-direction,” Turkish Online J. Distance Educ., vol. 17, no. 4, hlm. 31-45, 2016.

[7] F. Karakas dan A. Manisaligil, "Reorienting self-directed learning for the creative digital era," Eur. J. Train. Dev., vol. 36, no. 7, hlm. 712-731, 2012.

[8] R. Rusli, A. Rahman, dan H. Abdullah, "Student perception data on online learning using heutagogy approach in the Faculty of Mathematics and Natural Sciences of Universitas Negeri Makassar, Indonesia," Data Br., vol. 29, hlm. 105152, 2020, doi: https://doi.org/10.1016/j.dib.2020.105152.

[9] L. M. Blaschke dan S. . Hase, "Heutagogy: A Holistic Framework for Creating Twenty-First-Century Self-determined Learners," in The Future of Ubiquitous Learning, Lecture Notes in Educational Technology, B. Gros dan M. M. Kinshuk, Ed. Berlin Heidelberg: Spring Verlag, 2016.

[10] A. K. Hia, "Model pendidikan dan pelatihan berbasis manajemen heutagogy dalam peningkatan perilaku kewirausahaan yang sustainabel (studi pada para pegawai PT Bank Rakyat Indonesia (Persero) Tbk," Universitas Pendidikan Indonesia, 2018.

[11] M. Littledyke, E. Manolas, dan R. A. Littledyke, "A systems approach to education for sustainability in higher education," Int. J. Sustain. High. Educ., vol. 14, no. 4, hlm. 367-383, 2013.

[12] A. Glassner dan S. Back, Exploring Heutagogy in Higher Education. United States: Springer, 2020.

[13] R. L. Moore, "Developing lifelong learning with heutagogy: contexts, critiques, and challenges," Distance Educ., vol. 41, no. 3, hlm. 381-401, 2020.

[14] M. . Bailey, "Developmentalism - from here to there - is heutagogy the way there for HR?.UK," University of Stirling, 2013.

[15] I. Widiaty, A. L. S. Riza, A. G. Abdullah, dan S. R. Mubaroq, "Multiplatform Application Technology - Based Heutagogy on Learning Batik: A Curriculum Development Framework," Indones. J. Sci. Technol., vol. 5, no. 1, hlm. 45-61, 2020.

[16] D. W. Stoten, "Building adaptive management capability: the contribution of heutagogy to management development in turbulent times," J. Manag. Dev., vol. 40, no. 2, hlm. 121-137, 2021.

[17] G. Vinayan, D. Harikirishanan, dan S. W. Ling, "upskilling and reskilling the workforce via Industry driven technical and vocational Education and training: strategies to initiate Industry/institution partnership in malaysia," J. Econ. Info, vol. 7, no. 2, hlm. 94-103, 2020.

[18] E. Ghauri, "Performance evaluation of sales employees: a comparative investigation in the pharmaceutical industry," Int. J. Bus. Perform. Manag., vol. 19, no. 3, hlm. 253, 2018.

[19] E. . Winter, T. M. Litvinova, D. V. Babaskin, L. I. Bbaskina, dan V. Savinova, O, "marketing analysis of the medical representatives' activity aimed on Information support for promoted medications," Entrep. Sustain. Issues, vol. 7, no. 1, hlm. 177$187,2019$. 
[20] M. Khazzaka, "Pharmaceutical marketing strategies' influence on physicians' prescribing pattern in Lebanon: ethics, gifts, and samples," BMC Health Serv. Res., vol. 19, no. 1, 2019.

[21] S. Stenman dan F. Pettersson, "Remote teaching for equal and inclusive education in rural areas? An analysis of teachers' perspectives on remote teaching," Int. J. Inf. Learn. Technol., vol. 37, no. 3, hlm. 87-98, 2020.

[22] N. A. Kamrozzaman, J. Badusah, dan W. M. Ruzanna, "Development of heutagogy approach in M-learning for sustainability education," Educ. Inf. Technol., vol. 25, no. 4, hlm. 3035-3047, 2020, doi: 10.1007/s10639-020-10101-x.

[23] Y. Masnita, A. Rahman, dan A. Veraldy, "inovasi memediasi tqm dan kinerja perusahaan pada sektor UKM," J. Manaj. Ind. dan Logistik, vol. 13, no. 02, hlm. 155$163,2019$.

[24] L. M. Blaschke dan V. Marin, "Aplicaciones de la heutagogía en el uso educativo de eportfolios," Rev. Educ. a Distancia, vol. 20, no. 64, 2020, doi: 10.6018/red.407831.

[25] S. Darwish, U. Ahmed, dan M. H. Pahi, "Innovative Work Behavior during COVID-19 for Medical Representatives in the Pharmaceutical Industry: Test of a Moderation Model in Bahrain," Int. J. Pharm. Res., vol. 12, no. 4, hlm. 1927-1993, 2020.

[26] C. Jones, H. Matlay, K. Penaluna, dan A. Penaluna, "Claiming the future of enterprise education," Educ. + Train., vol. 56, no. 8/9, hlm. 764-775, 2014.

[27] L. M. Blaschke, "The dynamic mix of heutagogy and technology: Preparing learners for lifelong learning," Br. J. Educ. Technol., vol. 52, no. 3, Mei 2021, doi: 10.1111/bjet.13105.

[28] D. Kisahwan dan A. . Gunawan, "Predicting Turnover Intention Among Pharmaceutical Employee Through Psychological Contract Fulfillment For Work Engagement," Adv. Econ. Bus. Manag. Res., vol. 151, hlm. 1-5, 2020. 